\title{
Fluorescence of chlorophyll a and photosynthetic pigments in Atriplex nummularia under abiotic stresses
}

\author{
Hidelblandi F. de Melo${ }^{1}$, Edivan R. de Souza ${ }^{1} \&$ Jailson C. Cunha ${ }^{2}$ \\ ${ }^{1}$ Universidade Federal Rural de Pernambuco/Departamento de Agronomia/Programa de Pós-graduação em Ciência do Solo. Recife, PE. E-mail: \\ hidelfarias@gmail.com; edivan.rodrigues@ufrpe.br (Corresponding author) \\ ${ }^{2}$ Universidade Federal do Vale do São Francisco/Campus Ciências Agrárias. Petrolina, PE. E-mail: jailson.c.c@gmail.com
}

\section{Key words:}

photosynthesis

water and salt stress

halophyte

\begin{abstract}
A B S T R A C T
Chlorophyll a fluorescence is a very useful tool in ecophysiological studies to analyze the photosynthetic performance of plants under biotic and abiotic stresses. This research aimed to evaluate the parameters of the fluorescence of chlorophyll a, contents of chlorophyll a, $\mathrm{b}$ and total, and carotenoids in Atriplex nummularia cultivated under water stress ( 37 and $70 \%$ of field capacity) and salt stress (irrigation water with electrical conductivity of 0,5 , $10,20,30$ and $40 \mathrm{dS} \mathrm{m}^{-1}$ ), besides two sources of salts: $\mathrm{NaCl}$ and a mixture of salts of $\mathrm{Ca}^{2+}$, $\mathrm{Mg}^{+2}, \mathrm{~K}^{+}, \mathrm{Na}^{+}$and $\mathrm{Cl}^{-}$, in a $6 \times 2 \times 2$ factorial, with 4 replicates, totaling 96 experimental plots. At 91 days after transplanting, the initial fluorescence $\left(\mathrm{F}_{0}\right)$, maximum fluorescence $\left(\mathrm{F}_{\mathrm{m}}\right)$, potential quantum efficiency of photosystem II $\left(\mathrm{F}_{\mathrm{v}} / \mathrm{F}_{\mathrm{m}}\right), \mathrm{F}_{\mathrm{v}} / \mathrm{F}_{0}$ ratio and the contents of chlorophyll a, b, and total and carotenoids were determined. All assessed parameters decreased as a standard response to salt stress, except $\mathrm{F}_{0}$, which had, as a characteristic, the increase in its values under stress conditions. The emission parameters for Atriplex nummularia varied with the type of salt present in the irrigation water.
\end{abstract}

\section{Palavras-chave: fotossíntese estresse salino e hídrico halófita}

\section{Fluorescência da clorofila a e pigmentos fotossintéticos em Atriplex nummularia sob estresses abióticos}

\begin{abstract}
R E S U M O
A fluorescência da clorofila a é uma ferramenta de grande utilidade em estudos ecofisiológicos para a análise da performance fotossintética de plantas sob estresses bióticos e abióticos. Objetivou-se avaliar os parâmetros da fluorescência da clorofila a, teores de clorofila a, b e total e carotenoides em Atriplex nummularia cultivada sob estresses hídrico (37 e 70\% da capacidade de campo) e salino (água de irrigação com condutividade elétrica de $0,5,10,20$, 30 e $40 \mathrm{dS} \mathrm{m}{ }^{-1}$ ), além de duas fontes de sais: $\mathrm{NaCl}$ e uma mistura com sais de $\mathrm{Ca}^{2+}, \mathrm{Mg}^{2+}, \mathrm{K}^{+}$, $\mathrm{Na}^{+}$e Cl- em fatorial $6 \times 2 \times 2$ com 4 repetições totalizando 96 parcelas experimentais. Aos 91 dias após o transplantio foram determinadas a fluorescência inicial $\left(\mathrm{F}_{0}\right)$, a fluorescência máxima $\left(\mathrm{F}_{\mathrm{m}}\right)$, a eficiência quântica potencial do fotossistema $\mathrm{II}\left(\mathrm{F}_{\mathrm{v}} / \mathrm{F}_{\mathrm{m}}\right)$ e a razão $\mathrm{F}_{\mathrm{v}} / \mathrm{F}_{0}$ e os teores de clorofila a, b, total e carotenoides. Os parâmetros de emissão avaliados reduziram como resposta padrão ao estresse salino, com exceção do $\mathrm{F}_{0}$ que tem, como característica, $\mathrm{o}$ aumento de seus valores quando em condições de estresse. Os parâmetros de emissão para a Atriplex nummularia variaram de acordo com o tipo de sal presente na água de irrigação.
\end{abstract}




\section{INTRODUCTION}

The use of chlorophyll a and photosynthetic pigments is an important tool to evaluate the performance in the light energy harvest by plants under abiotic stress (Shu et al., 2013). The high concentration of salts causes damages to the photosynthetic apparatus and to the metabolic processes in most plants (Glenn et al., 2012). Under these conditions, the contents of pigments constituting the antenna complex may be reduced, leading to a deficit in the harvest of light energy (Bouchenak et al., 2012).

The integrity of the photosynthetic apparatus and the photosynthetic rates are among the main metabolic phenomena affected by salt and water stresses (Glenn et al., 2012). Thus, the evaluation and monitoring of these metabolic phenomena can be used as quantitative and qualitative tools of the stress level and damages associated with it (Ahmed et al., 2012; Shu et al., 2013).

The use of fluorescence parameters allows to analyze, qualitatively and quantitatively, the absorption and use of light energy, besides detecting possible damages in the photosynthetic apparatus of the plant (Vieira et al., 2010; Azevedo Neto et al., 2011). Non-invasive and non-destructive techniques allow the researcher to evaluate the plant during a longer period along the crop cycle and make more-consistent inferences about any hypotheses tested (Baker, 2008). Atriplex nummularia is a halophyte widely used in soils degraded by salinity and has been the target of studies in the Northeastern semi-arid region (Souza et al., 2011; 2012; 2014; Melo et al., 2016); however, investigations on its photosynthetic apparatus are still necessary.

This research aimed to evaluate alterations in the parameters of fluorescence emission, as well as in the contents of chlorophyll a, b and total and carotenoids (carotenes + xanthophylls) in Atriplex nummularia in response to water and salt stresses.

\section{Material AND Methods}

The soil used in the experiment was collected in the municipality of Pesqueira-PE, Brazil, in the layer of 0-30 cm, classified as Fluvic Neosol (EMBRAPA, 2013), free from problems of salinity and sodicity. Subsequently, the soil was air-dried, pounded to break up clods, homogenized and sieved through a $4-\mathrm{mm}$ mesh, thus preserving its microaggregation.

The soil was chemically characterized (Table 1) using air dried fine earth (ADFE), through the determination of $\mathrm{pH}_{\mathrm{H} 2 \mathrm{O}}$ at the ratio of 1:2.5. The exchangeable cations $\mathrm{Ca}^{2+}, \mathrm{Mg}^{2+}, \mathrm{Na}^{+}$and $\mathrm{K}^{+}$were extracted using $1 \mathrm{~mol} \mathrm{~L}^{-1}$ ammonium acetate (Thomas, 1982). The saturation extract was obtained by preparing the saturation paste (USSLS, 1954), which was analyzed for electrical conductivity (EC) and $\mathrm{pH}$, determining the soluble
Table 1. Chemical characterization of the Fluvic Neosol

\begin{tabular}{|c|c|}
\hline Variables & Values \\
\hline \multicolumn{2}{|c|}{ Saturation extract } \\
\hline $\mathrm{pH}_{\mathrm{se}}{ }^{1 /}$ & 8.17 \\
\hline $\mathrm{EC}\left(\mathrm{dS} \mathrm{m}^{-1}\right)$ & 1.17 \\
\hline $\mathrm{Ca}^{2+}\left(\mathrm{mmol}_{\mathrm{C}} \mathrm{L}^{-1}\right)$ & 1.00 \\
\hline $\mathrm{Mg}^{2+}\left(\mathrm{mmol}_{\mathrm{C}} \mathrm{L}^{-1}\right)$ & 1.04 \\
\hline $\mathrm{Na}^{+}\left(\mathrm{mmol}_{\mathrm{c}} \mathrm{L}^{-1}\right)$ & 5.34 \\
\hline $\mathrm{K}^{+}\left(\mathrm{mmol}_{\mathrm{C}} \mathrm{L}^{-1}\right)$ & 1.12 \\
\hline $\mathrm{Cl}^{-}\left(\mathrm{mmol}_{\mathrm{c}} \mathrm{L}^{-1}\right)$ & 6.804 \\
\hline \multicolumn{2}{|c|}{ Exchange complex } \\
\hline $\mathrm{pH}_{(1: 2.5)}$ & 7.70 \\
\hline $\mathrm{Ca}^{2+}\left(\mathrm{cmol}_{\mathrm{c}} \mathrm{kg}^{-1}\right)$ & 5.53 \\
\hline $\mathrm{Mg}^{2+}\left(\mathrm{cmol}_{\mathrm{c}} \mathrm{kg}^{-1}\right)$ & 2.22 \\
\hline $\mathrm{Na}^{+}\left(\mathrm{cmol}_{\mathrm{c}} \mathrm{kg}^{-1}\right)$ & 0.26 \\
\hline $\mathrm{K}^{+}\left(\mathrm{cmol}_{\mathrm{c}} \mathrm{kg}^{-1}\right)$ & 0.50 \\
\hline $\mathrm{SB}^{2 /}\left(\mathrm{cmol}_{\mathrm{c}} \mathrm{kg}^{-1}\right)$ & 8.51 \\
\hline \multicolumn{2}{|c|}{ Ratio (soluble) } \\
\hline $\mathrm{Na} / \mathrm{Ca}$ & 5.34 \\
\hline $\mathrm{Na} / \mathrm{Mg}$ & 5.13 \\
\hline $\mathrm{Na} / \mathrm{K}$ & 4.77 \\
\hline $\mathrm{Na} / \mathrm{Cl}$ & 0.79 \\
\hline $\mathrm{Cl} / \mathrm{Ca}$ & 6.80 \\
\hline $\mathrm{Cl} / \mathrm{Mg}$ & 6.54 \\
\hline $\mathrm{Cl} / \mathrm{Na}$ & 1.27 \\
\hline $\mathrm{Cl} / \mathrm{K}$ & 6.07 \\
\hline
\end{tabular}

${ }^{1} \mathrm{pH}$ determined in the saturation extract; ${ }^{2}$ Sum of Bases; ${ }^{3}$ Exchangeable sodium percentage

bases and the chloride ion, through the method of titration with $\mathrm{AgNO}_{3}$ (EMBRAPA, 1997). The cation exchange capacity (T) was determined through the index cation method using ammonium acetate as extractor (USSLS, 1954). The results for the exchange complex were used to calculate the values of sum of bases (SB) and exchangeable sodium percentage (ESP).

Physical characterization (Table 2) consisted of granulometric analysis and clay dispersed in water in the ADFE through the hydrometer method, calculating the indices of clay dispersion and flocculation, soil density through the cylinder method and particle density through the volumetric flask method (EMBRAPA, 1997). Field capacity and permanent wilting point were determined based on the soil-water retention characteristic curve (SWRCC). Total porosity was estimated using the values of particle and bulk density.

The experiment was carried out in a greenhouse at the Federal Rural University of Pernambuco, during the months from March to June 2013, totaling 100 days of monitoring. A. nummularia plants were cultivated in pots with capacity for $10 \mathrm{~L}$ per pot. After transplanting, the plants were subjected to two soil gravimetric moisture contents: $0.17 \mathrm{~g} \mathrm{~g}^{-1}(-0.06 \mathrm{MPa})$, referring to $70 \%$ of field capacity and $0.09 \mathrm{~g} \mathrm{~g}^{-1}(-0.52 \mathrm{MPa})$, referring to $37 \%$ of field capacity. The moisture contents were selected based on the SWRCC. The waters for irrigation were prepared in the laboratory using two sources of salts, one composed of $\mathrm{NaCl}$ and the other composed of a mixture of salts in proportions similar to those found in a well located in the experimental area, which were produced maintaining

Table 2. Physical characterization of the Fluvic Neosol

\begin{tabular}{|c|c|c|c|c|c|c|c|c|c|c|c|c|}
\hline \multicolumn{3}{|c|}{ Sand } & \multirow{2}{*}{ Silt } & \multirow{2}{*}{ Clay } & \multirow{2}{*}{ CDW $^{1 /}$} & \multirow{2}{*}{$\mathrm{Ds}^{2 /}$} & \multirow{2}{*}{$D p^{3 /}$} & \multirow{3}{*}{ ID ${ }^{4 /}$} & \multirow{3}{*}{ IF $^{5 /}$} & \multirow{3}{*}{$\begin{array}{c}\mathrm{TP}^{6 /} \\
\%\end{array}$} & $\mathrm{FC}^{7 /}$ & PWP8/ \\
\hline \multirow{2}{*}{\multicolumn{6}{|c|}{$\mathrm{g} \mathrm{kg}^{-1}$}} & & & & & & & \\
\hline & & & & & & \multicolumn{2}{|c|}{$\mathrm{kg} \mathrm{dm}^{-3}$} & & & & \multicolumn{2}{|c|}{$\mathrm{g} \mathrm{g}^{-1}$} \\
\hline 435 & 17 & 452 & 386 & 162 & 117 & 1.36 & 2.66 & 0.72 & 0.28 & 48.87 & 0.24 & 0.05 \\
\hline
\end{tabular}

${ }^{1}$ Clay dispersed in water; ${ }^{2}$ Soil bulk density; ${ }^{3}$ Soil particle density; ${ }^{4}$ Index of dispersion (CDW/Clay) $;{ }^{5}$ Index of flocculation [IF: (1 - ID)]; ${ }^{6}$ Total porosity; ${ }^{7}$ Field capacity; ${ }^{8}$ Permanent wilting point 
six values of electrical conductivity: $0,5,10,20,30$ and 40 $\mathrm{dS} \mathrm{m} \mathrm{m}^{-1}$ (Araújo et al., 2006; Silveira et al., 2009; Belkheiri \& Mulas, 2013).

In order to justify the composition of the mixture of salts necessary for the treatments, water samples were collected in an Artesian well located close to the area of soil collection. The samples were analysed for the determination of $\mathrm{pH}$, electrical conductivity, $\mathrm{Ca}^{2+}, \mathrm{Mg}^{2+}$, through atomic absorption spectrophotometry, $\mathrm{Na}^{+}$and $\mathrm{K}^{+}$, through flame photometry, and $\mathrm{Cl}^{-}$through the Mohr method (EMBRAPA, 1997).

After determination of the chemical composition and the proportion of each element in the samples, salts of $\mathrm{NaCl}, \mathrm{KCl}, \mathrm{MgCl}_{2}$ and $\mathrm{CaCl}_{2}$ were weighed to maintain the same proportion of the samples (Table 3 ) and the electrical conductivity of the solution was determined.

To guarantee genetic uniformity, clones of a single plant were used, produced through cuttings and cultivated in unfertilized substrate (material composed of clay, sand and humus), obtained in seedling trays. The cuttings were cultivated in greenhouse and transplanted 90 days after propagation.

The seedlings were transplanted one day after establishment and equilibrium of the moisture content required in each treatment. Plants were initially irrigated with distilled water for a period of 20 days, with gradual increase (EC increased every two days to achieve the highest value) to avoid osmotic shock on the transplanted plants. Along the entire experiment, the moisture content in the pots was maintained by weighing and replenishment of the volume evapotranspired every day, always in the late afternoon, to allow the soil to come into equilibrium with the desired moisture content during the night.

The variables of chlorophyll a fluorescence [initial fluorescence $\left(\mathrm{F}_{0}\right)$, variable fluorescence $\left(\mathrm{F}_{\mathrm{v}}\right)$, maximum fluorescence $\left(\mathrm{F}_{\mathrm{m}}\right)$ and quantum yield $\left(\mathrm{F}_{\mathrm{v}} / \mathrm{F}_{\mathrm{m}}\right)$ and $\left.\left(\mathrm{F}_{\mathrm{v}} / \mathrm{F}_{0}\right)\right]$ were measured using a fluorometer, FluorPen, model F100 (Photon Systems Instruments), at 91 days after transplanting. The measurements were taken in healthy, fully expanded leaves from the middle third section, exposed to the sun. After the measurements, the leaves were collected for the determination of the contents of chlorophyll $\mathrm{a}, \mathrm{b}$ and carotenoids.

The contents of chlorophylls $\mathrm{a}, \mathrm{b}$ and carotenoids were determined according to Lichtenthaler \& Buschmann (2001).

The treatments were arranged in a randomized block design, with four replicates in a $6 \times 2 \times 2$ triple factorial scheme, corresponding to six levels of electrical conductivity $(0,5$, $10,20,30$ and $\left.40 \mathrm{dS} \mathrm{m}^{-1}\right)$; two matric tensions ( 0.06 and 0.52 $\mathrm{MPa}$ ) and two sources of salts, $\mathrm{NaCl}$ and a mixture of salts of $\mathrm{CaCl}_{2}, \mathrm{MgCl}_{2}, \mathrm{NaCl}$ and $\mathrm{KCl}$, with four replicates, totaling 96 experimental units. After the tests of assumptions (homogeneity of variances and normality), the data were subjected to analysis of variance, test of comparison of means and fits of regressions for the interactions with the salinity levels.

\section{Results AND Discussion}

Due to the increase in salinity, plants subjected to 37 and $70 \%$ of field capacity and different sources of salts showed trend of reduction in chlorophyll a fluorescence for all evaluated parameters (Figures 1 and 2), except $\mathrm{F}_{0}$, which increased with the increment of salts up to the EC of $20 \mathrm{dS} \mathrm{m}^{-1}$ at the soil moisture corresponding to $70 \%$ field capacity (Figure 1A).

Under salt stress, the increase in $\mathrm{F}_{0}$ values eventually indicates damages to the PSII reaction center (Baker, 2008), a behavior observed in plants subjected to $70 \% \mathrm{FC}$, in which the higher evaporation demand resulted in greater entry of salts through irrigation water, leading to increments in $\mathrm{F}_{0}$ values.

Increments in $\mathrm{F}_{0}$ values associated with reductions in $\mathrm{F}_{\mathrm{m}}$ values can be interpreted as an indication of the damage in the

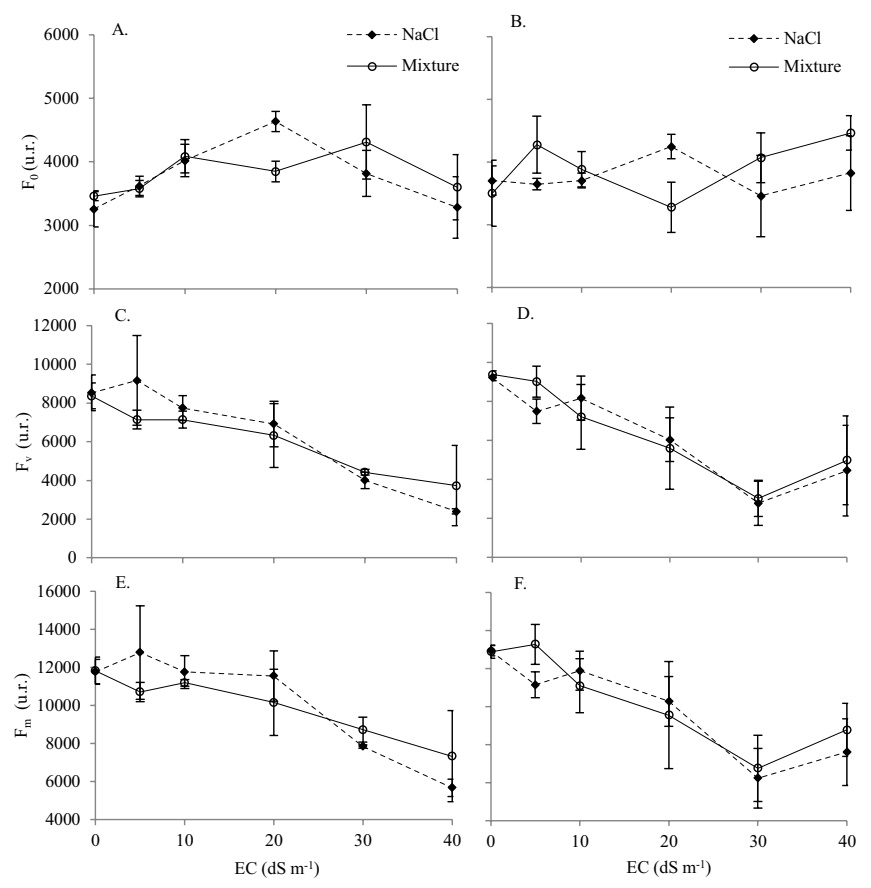

Bars indicate standard deviation around the mean

Figure 1. Effect of the increase in salinity on the parameters of chlorophyll a fluorescence in leaves of Atriplex nummularia cultivated at levels of electrical conductivity (EC), soil moisture (70\%: A, C and E; 37\%: B, D and F) and different sources of salts

Table 3. Amounts of salts $\left(\mathrm{g} \mathrm{L}^{-1}\right)$ necessary to obtained the values of electrical conductivity (EC) used for the irrigation waters of both sources of salts and the osmotic potential of the solutions $\left(\Psi_{0}\right)$

\begin{tabular}{|c|c|c|c|c|c|c|c|c|}
\hline \multirow{3}{*}{$\begin{array}{c}E C \\
\mathrm{dS} \mathrm{m}^{-1}\end{array}$} & \multicolumn{8}{|c|}{ Sources of water } \\
\hline & \multicolumn{2}{|c|}{$\mathrm{NaCl}$} & \multicolumn{6}{|c|}{ Mixture of salts } \\
\hline & $\mathrm{NaCl}$ & $\Psi_{0}^{1 /}$ & $\mathrm{NaCl}$ & $\mathrm{KCl}$ & $\mathrm{MgCl}_{2}$ & $\mathrm{CaCl}_{2}$ & Total & $\Psi_{0}^{1 /}$ \\
\hline 0 & - & -0.02 & - & - & - & - & - & -0.02 \\
\hline 5 & 2.2202 & -0.21 & 1.6688 & 0.0100 & 0.4705 & 0.3769 & 2.5263 & -0.19 \\
\hline 10 & 5.2591 & -0.30 & 4.3744 & 0.0262 & 1.2333 & 0.9881 & 6.6222 & -0.58 \\
\hline 20 & 13.279 & -1.24 & 10.619 & 0.0637 & 2.9941 & 2.3988 & 16.0760 & -1.17 \\
\hline 30 & 23.128 & -2.21 & 20.454 & 0.1228 & 5.7672 & 4.6206 & 30.9655 & -2.31 \\
\hline
\end{tabular}

Osmotic potential in $\mathrm{MPa}$ 


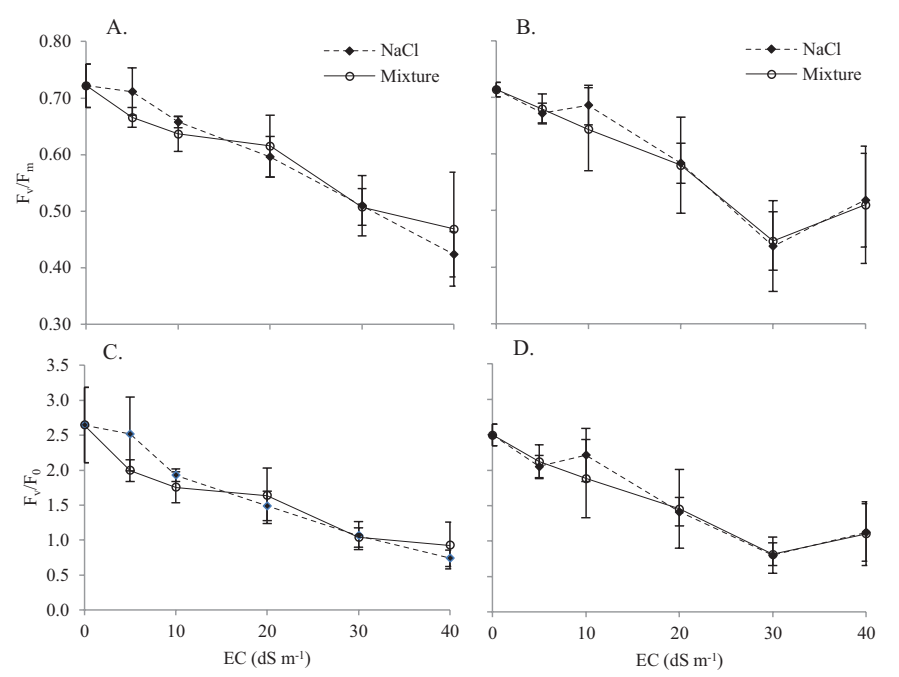

Bars indicate standard deviation around the mean

Figure 2. Maximum quantum yield of PSII $\left(\mathrm{F}_{v} / \mathrm{F}_{\mathrm{m}}\right)$ and $\mathrm{F}_{\sqrt{ }} / \mathrm{F}_{0}$ ratio of leaves of Atriplex nummularia cultivated at levels of electrical conductivity (EC), soil moisture $(70 \%$ : A and C; $37 \%$ : B and D) and different sources of salts

light-harvesting complex of PSII (Fernandez et al., 1997; Li et al., 2010), as observed in the present study. On the other hand, the reduction of $F_{v}$ and $F_{m}$ was due to the decrease in the levels of chlorophyll with the increment in EC. The reduction in the parameters of chlorophyll a fluorescence with the increment in salinity was also reported by Correia et al. (2009) in peanut irrigated with saline water $\left(\mathrm{EC} 6.0 \mathrm{dS} \mathrm{m}^{-1}\right)$ and is directly related to the degradation of chlorophyll due to the ionic toxicity.

Hence, the differences of $\mathrm{F}_{\mathrm{v}}$ and $\mathrm{F}_{\mathrm{m}}$ between the moisture contents represent the higher damages caused by the water deficit to the photosynthetic apparatus between the same levels of salinity, at which $\mathrm{F}_{\mathrm{v}}$ and $\mathrm{F}_{\mathrm{m}}$ were more sensitive than $\mathrm{F}_{0}$, especially at the highest EC values (Figure 1).

According to Azevedo Neto et al. (2011), the $\mathrm{F}_{\mathrm{v}} / \mathrm{F}_{\mathrm{m}}$ ratio has been used to detect disturbances in the photosynthetic system favored by salt stress, since its decrease indicates a reduction in the photochemical efficiency of PSII and damages to the photosynthetic apparatus. According to Bjorkman \& Demming (1987), $F_{v} / F_{m}$ is virtually constant for different species when measured under no-stress conditions and the photosynthetic apparatus of the plant is intact, being equal to $0.75 \leq \mathrm{F}_{\mathrm{v}} / \mathrm{F}_{\mathrm{m}} \leq$ 0.86 .

Increments in the values of $\mathrm{F}_{\mathrm{v}} / \mathrm{F}_{\mathrm{m}}$ indicate increase in the photosynthetic conversion efficiency of PSII (Shu et al., 2013; Mehta et al., 2011). The values of $\mathrm{F}_{\mathrm{v}} / \mathrm{F}_{\mathrm{m}}$ presented in the literature ( $\mathrm{Li}$ et al., 2010; Shu et al., 2013) for plants under no-stress conditions $(0.75)$ are above those observed in the present study (0.72).

Bjorkman \& Demmin (1987), working with the fluorescence parameters in Atriplex triangularis, observed $\mathrm{F}_{\mathrm{v}} / \mathrm{F}_{\mathrm{m}}$ values of 0.805 for plants with intact photosynthetic apparatus. Such result contrasts with that found in this research, not corresponding to the values of plants under conditions of no stress. It should be noticed that the difference between plants under high moisture and water deficit was not more than 0.01 (Figure 2). Thus, only the water stress applied in the present study was not sufficient to reduce the values of $F_{v} / F_{m}$.
The $\mathrm{F}_{\mathrm{v}} / \mathrm{F}_{0}$ ratio is a very sensitive indicator of the potential photosynthetic activity, in both stressed and healthy plants (Ozfidan et al., 2013). The evaluation of $\mathrm{F}_{\mathrm{v}} / \mathrm{F}_{0}$ has also been recommended to detect changes induced by salt stress, since it amplifies the small variations detected by the $\mathrm{F}_{\mathrm{v}} / \mathrm{F}_{\mathrm{m}}$ ratio (Azevedo Neto et al., 2011).

Reductions in these values in plants under severe salt stress indicate that the efficiency of the photosynthetic process and electron transport chain were affected (Li et al., 2010; Shu et al., 2013). Thus, analyzing these variables in A. nummularia plants, it is possible to observe the reduction in the photochemical efficiency of PSII (Figures 2A and 2C), when there is an increment in irrigation water EC.

In general, the reductions in the quantum yield of PSII can be associated with the degradation of chlorophyll (Figure $2 \mathrm{~A}$ and $2 \mathrm{~B}$ ), since there was a decrease in the contents of chlorophyll, especially chlorophyll a, in the leaves of $A$. nummularia with the increment in salinity (Figure 3A).

The chlorophyll content is an important physiological index directly related to photosynthesis in plants (Ma et al., 2011). The reduction in the chlorophyll contents in Atriplex is associated with the damages caused by the increase in salinity (Nedjimi, 2014). The degradation of chlorophyll in plants under abiotic stress can be partially attributed to the sensitivity of the membranes to the oxidative stress (Hasegawa et al., 2000).

These environmental conditions lead to the increment in the level of reactive oxygen species, culminating in the

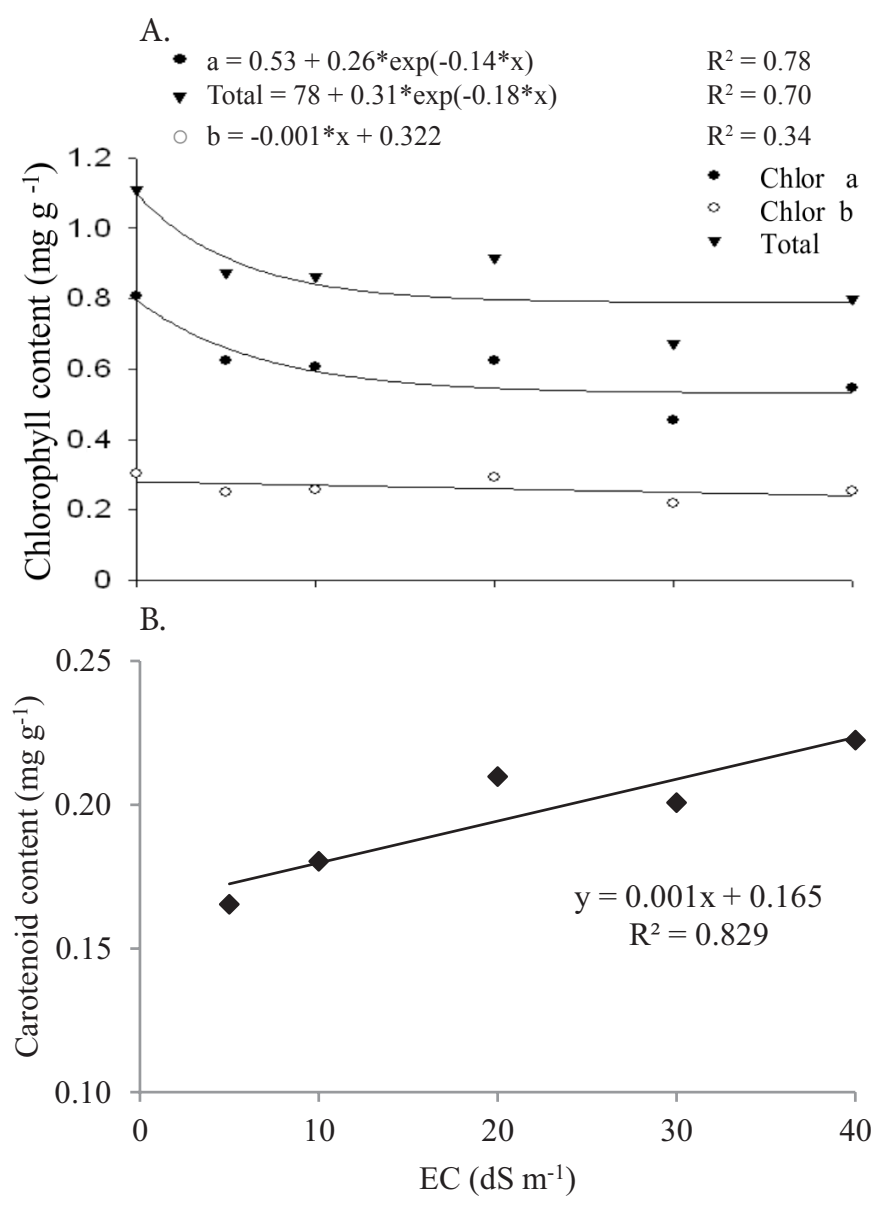

Figure 3. Contents of chlorophyll (A) and carotenoids (B) in leaves of Atriplex nummularia Lindl, 91 days after transplanting as a function of the electrical conductivity (EC) levels 
peroxidation of the lipid of the membranes, disintegration of thylakoids and reduction in chlorophyll concentration (Paridas \& Das, 2005; Ma et al., 2011).

Therefore, Atriplex plants were more efficient in the accumulation of carotenoids with the increment of salts in the irrigation water (Figure 3B). The increase of carotenoids can be associated with mechanisms of protection to the antenna complex, since they act as reducing agents and protecting pigments of oxidative reactions.

\section{Conclusions}

1. The reductions in the contents of chlorophyll $a, b$ and total indicate possible oxidative stress and degradation of membranes in plants subjected to high salt concentrations.

2. The increment in salinity up to the maximum studied value of electrical conductivity increases the contents of carotenoids in Atriplex leaves, avoiding greater damages to the photosynthetic apparatus.

3. Atriplex plants were more sensitive to salt stress than to water stress.

4. Plants were more affected by the mixture of salts when subjected to the first four values of electrical conductivity and, from these levels on, they were more sensitive to $\mathrm{NaCl}$.

\section{Literature Cited}

Ahmed, C. B.; Magdich, S.; Rouina, B. B.; Boukhris M.; Abdullah F.B. Saline water irrigation effects on soil salinity distribution and some physiological responses of field grown Chemlali olive. Journal of Environmental Management, v.113, p.538-544, 2012. https://doi.org/10.1016/j.jenvman.2012.03.016

Araújo, S. A. M.; Silveira, J. A. G.; Almeida, T. D.; Rocha, I. M. A.; Morais, D. L.; Viégas, R. A. Salinity tolerance of halophyte Atriplex nummularia L. grown under increasing $\mathrm{NaCl}$ levels. Revista Brasileira de Engenharia Agrícola e Ambiental, v.10, p.848-854, 2006. https://doi.org/10.1590/S1415-43662006000400010

Azevedo Neto, A. D.; Pereira, P. P. A.; Costa, D. P.; Santos A. C. C. Fluorescência da clorofila como ferramenta possível para a seleção de tolerância à salinidade em girassol. Revista Ciência Agronômica, v.42, p.893-897, 2011. https://doi.org/10.1590/ S1806-66902011000400010

Baker, N. R. Chlorophyll fluorescence: A probe of photosynthesis in vivo. Annual Review of Plant Biology, v.113, p.59-89, 2008. https:// doi.org/10.1146/annurev.arplant.59.032607.092759

Belkheiri, O.; Mulas, M. The effects of salt stress on growth, water relations and ion accumulation in two halophyte Atriplex species. Environmental and Experimental Botany, v.86, p.1-12, 2013. https://doi.org/10.1016/j.envexpbot.2011.07.001

Bjorkman, O.; Deming, B. Photon yield of $\mathrm{O}_{2}$ evolution and chrolophyll fluorescence characteristics at $77 \mathrm{~K}$ among vascular plants of diverse origins. Planta, v.170, p.489-504, 1987. https:// doi.org/10.1007/BF00402983

Bouchenak, F.; Henri, P.; Benrebiha, F.Z.; Rey, P. Differential responses to salinity of two Atriplex halimus populations in relation to organic solutes and antioxidant systems involving thiolreductases. Journal of Plant Physiology, v.169, p.1445-1453, 2012. https://doi.org/10.1016/j.jplph.2012.06.009
Correia, K. G.; Fernandes, P. D.; Gheyi, H. R.; Nobre, R. G.; Santos, T. S. Crescimento, produção e características de fluorescência da clorofila a em amendoim sob condições de salinidade. Revista Ciência Agronômica, v.40, p.514-521, 2009.

EMBRAPA - Empresa Brasileira de Pesquisa Agropecuária. Manual de métodos de análise de solo. 2.ed. Rio de Janeiro: Centro Nacional de Pesquisa de Solos, 1997. 212p.

EMBRAPA - Empresa Brasileira de Pesquisa Agropecuária. Sistema brasileiro de classificação de solos. Brasília: Centro Nacional de Pesquisa de Solos, 2013. 353p.

Fernandez, R. T.; Perry, R. L.; Flore, J. A. Drought response of young apple trees on three rootstocks II. Gas exchange, chlorophyll fluorescence, water relations, and leaf abscisic acid. Journal American Society Horticulture Science, v.122, p.841-848, 1997.

Glenn, E. P.; Nelson, S. G.; Ambrose, B.; Martinez, R.; Soliz, D.; Pabendinskas, V.; Hultine, K. Comparison of salinity tolerance of three Atriplex spp. in well-watered and drying soils. Environmental and Experimental Botany, v.83, p.62-72, 2012. https://doi.org/10.1016/j.envexpbot.2012.04.010

Hasegawa, P. M.; Bressan, R. A.; Zhu, J. K.; Bohnert, H. J. Plant cellular and molecular responses to high salinity. Annual Review of Plant Physiology, v.51, p.63-99, 2000. https://doi.org/10.1146/annurev. arplant.51.1.463

Li, G.; Wan, S.; Zhou, J.; Yang, Z.; Qin, P. Leaf chlorophyll fluorescence, hyperspectral reflectance, pigments content, malondialdehyde and proline accumulation responses of castor bean (Ricinus communis L.) seedlings to salt stress levels. Industrial Crops and Products, v.31, p.13-19, 2010. https://doi.org/10.1016/j.indcrop.2009.07.015

Lichtenthaler, H. K.; Buschmann, C. Chlorophylls and carotenoids: Measurement and characterization by UV-VIS spectroscopy. In: Wrolstad, R. E.; Acree, T. E.; An, H.; Decker, E. A.; Penner, M. H.; Reid, D. S.; Schwartz, S. J.; Shoemaker, C. F.; Sporns, P. (ed.) Current protocols in food analytical chemistry (CPFA). New York: Wiley. F4.3.1-F4.3.8. 2001.

Ma, Q.;Yue, L. J.; Zhang, J. L.; Wu, G. Q.;Bao, A.K.; Wang, S. M.Sodium chloride improves photosynthesis and water status in the succulent xerophyte Zygophyte xanthoxylum. Tree Physilology, v.32, p.4-13, 2011. https://doi.org/10.1093/treephys/tpr098

Mehta, P.; Kraslavsky, V.; Bharti, S.; Allakhverdiev, S. I.; Jajoo, A. Analysis of salt stress induced changes in Photosystem II heterogeneity by prompt fluorescence and delayed fluorescence in wheat (Triticum aestivum) leaves. Journal of Photochemistry and Photobiology B: Biology, v.104, p.308-313, 2011. https://doi. org/10.1016/j.jphotobiol.2011.02.016

Melo, H. F. de; Souza, E. R. de; Almeida, B. G. de; Freire, M. B. G. dos S.; Maia, F. E. Growth, biomass reduction and ions accumulation in Atriplex nummularia Lindl grown under abiotic stress. Revista Brasielira de Engenharia Agrícola e Ambiental, v.20, p.144-151, 2016. https://doi.org/10.1590/1807-1929/agriambi. v20n2p144-151

Nedjimi, B. Effects of salinity on growth, membrane permeability and root hydraulic conductivity in three saltbush species. Biochemical Systematics and Ecology, v.52, p.4-13, 2014. https:// doi.org/10.1016/j.bse.2013.10.007

Ozfidan, C.; Turkan, I.; Sekmen, A. H.; Seckin, B. Time course analysis of ABA and non-ionic osmotic stress-induced changes in water status, chlorophyll fluorescence and osmotic adjustment in Arabidopsis thaliana wild-type (Columbia) and ABA-deficient mutant (aba2). Environmental and Experimental Botany, v.86, p.44-51, 2013. https://doi.org/10.1016/j.envexpbot.2010.09.008 
Paridas, A. K.; Das, A. B. Salt tolerance and salinity effects on plants: A review. Ecotoxicology and Environmental Safety, v.60, p.324-349, 2005. https://doi.org/10.1016/j.ecoenv.2004.06.010

Shu, S.; Yuan, L. Y.; Guo, S. R.; Sun, J.; Yuan, Y. H. Effects of exogenous spermine on chlorophyll fluorescence, antioxidant system and ultrastructure of chloroplasts in Cucumis sativus L. under salt stress. Plant Physiology and Biochemistry, v.63, p.209-216, 2013. https://doi.org/10.1016/j.plaphy.2012.11.028

Silveira, J. A. G.; Araújo, S. A. M.; Lima, J. P. M. S.; Viégas, R. A. Roots and leaves contrasting osmotic adjustment mechanisms in responses to $\mathrm{NaCl}$-salinity in Atriplex nummularia. Environmental and Experimental Botany, v.66, p.1-8, 2009. https://doi. org/10.1016/j.envexpbot.2008.12.015

Souza, E. R. de; Freire, M. B. G. dos S.; Cunha, K. P. V.; Nascimento, C. W. A. do; Ruiz, H. A.; Lins, C. M. T. Biomass, anatomical changes and osmotic potential in Atriplex nummularia Lindl. cultivated in sodic saline soil under water stress. Environmental and Experimental Botany, v.82, p.20-27, 2012. https://doi. org/10.1016/j.envexpbot.2012.03.007
Souza, E. R. de; Freire, M. B. G. dos S.; Melo, D. V. M.; Montenegro, A. A. de A. Management of Atriplex nummularia Lindl. in a salt affected soil in a Semi Arid Region of Brazil. International Journal of Phytoremediation, v.16, p.73-85, 2014. https://doi.org/10.1080/ 15226514.2012.759529

Souza, E. R. de; Freire, M. B. G. dos S.; Nascimento, C. W. A. do; Montenegro, A. A. de A.; Freire, F. J.; Melo, H. F. de. Fitoextração de sais pela Atriplex nummularia Lindl. sob estresse hídrico em solo salino sódico. Revista Brasileira de Engenharia Agrícola e Ambiental, v.15, p.477-483, 2011. https://doi.org/10.1590/S1415-43662011000500007

Thomas, G. W. Exchangeable cations. In: Page, A. L. (ed.). Methods of soil analysis. Part-2. Chemical methods. Madison: American Society of Agronomy, 1982. p.159-165.

USSLS - United States Salinity Laboratory Staff. Diagnosis and improvement of saline and alkali soils. Washington: United States Department of Agriculture, 1954. 160p. Agriculture Handbook, 60

Vieira, D. A. de P.; Portes, T. de A; Stacciarini-Seraphin, E.; Teixeira, J. B. Fluorescência e teores de clorofilas em abacaxizeiro cv. Pérola submetido a diferentes concentrações de sulfato de amônio. Revista Brasileira de Fruticultura, v.32, p.360-368, 2010. https:// doi.org/10.1590/S0100-29452010005000061 